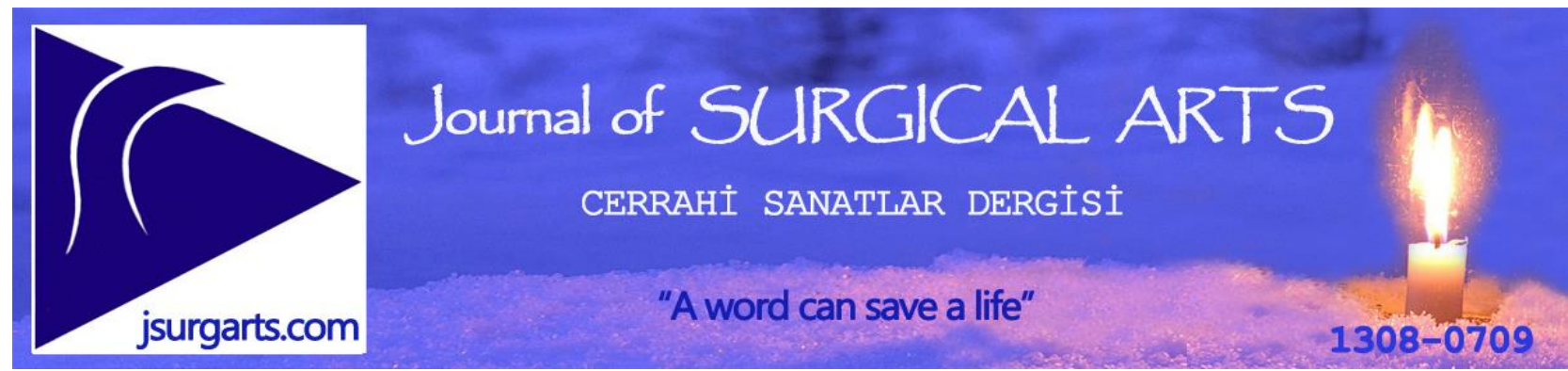

Clinical Practice Study

\title{
Pattern of surgical site infection in contaminated and infected wounds and corelation with introperative bacterial growth
}

\section{Kontamine ve enfekte yaralarda cerrahi alan enfeksiyonu paterni ve intraoperatif bakteri üremesi ile korelasyonu}

\begin{abstract}
Abhijit Acharya ${ }^{1}$, Kirtika Panda ${ }^{2}$, Ratna Chopra ${ }^{1}$
Hindu Rao Hospital \& NDMC Medical College, Departments of General Surgery ${ }^{1}$ and Microbiology ${ }^{2}$, New Delhi, India

Address: Dr. Abhijit Acharya (https://orcid.org/0000-0002-0653-9678), abhijitkirtika@gmail.com

How to cite: Acharya A, Panda K, Chopra R. Pattern of surgical site infection in contaminated and infected wounds and corelation with introperative bacterial growth. J Surg Arts:2021;14(1):17-21. DOI: https://doi.org/10.14717/jsurgarts-210104

Received:09.06.2020 Accepted: 12.10 .2020

\section{ABSTRACT}

Surgical Site Infections (SSIs), previously called post operative wound infections, result from bacterial contamination during or after a surgical procedure.Surgical site infections are the third most common hospital associated infection, accounting for 14-16\% of all infections in hospitalized patients.

Aims and objectives are to establish the pattern of wound infection in terms of aerobic organisms after contaminated and infected surgical procedures. 50 patients having emergency or elective traumatic or nontraumatic abdominal operations who fulfil the criteria of infected and contaminated wounds are included in the study. Patients to be studied were selected in random basis.

The incidence of wound infection is $31.57 \%$ in contaminated surgical procedures and $29.03 \%$ in infected surgical procedure. Operation in emergency set up results in an increased risk of wound infection. Patients with positive intra operative bacteriology runs a higher risk of developing wound infection. The commonest organism isolated from intra operative swab cultures were E. coli followed by Klebsiella in both infected and contaminated procedures. Presence of polymicrobial flora in intraoperative swab culture is associated with higher rate of wound infection.
\end{abstract}

Keywords: Surgical site infection; contamination; infection; antibiotic; treatment; wound.

\section{ÖZET}

Daha önce ameliyat sonrası yara enfeksiyonları olarak adlandırılan Cerrahi Alan Enfeksiyonları (SSI), bir cerrahi prosedür sırasında veya sonrasında bakteriyel kontaminasyondan kaynaklanır. Cerrahi bölge enfeksiyonları, hastanede yatan hastalarda tüm enfeksiyonların \%14-16'sını oluşturan üçüncü en yaygın hastane enfeksiyonudur.

Amaçlar ve hedefler, kontamine ve enfekte cerrahi prosedürlerden sonra aerobik organizmalar açısından yara enfeksiyonunun modelini belirlemektir. Çalışmaya acil veya elektif travmatik veya travmatik olmayan karın ameliyatı geçiren, enfekte ve kontamine yaralar kriterlerini karşılayan 50 hasta alındı. İncelenecek hastalar rastgele seçildi.

Yara enfeksiyonu insidansı kontamine cerrahi işlemlerde \%31.57 ve enfekte cerrahi işlemde \%29.03'tür. Acil operasyonlar yara enfeksiyonu riskinin artmasına neden olduğu saptanmıştır. Pozitif intraoperatif bakteriyolojisi olan hastalarda yara enfeksiyonu gelişme riski daha yüksektir. İntraoperatif sürüntü kültürlerinden izole edilen en yaygın organizma E. coli idi ve ardından hem enfekte hem de kontamine prosedürlerde Klebsiella 
izledi. İntraoperatif sürüntü kültüründe polimikrobiyal flora varlığı, daha yüksek yara enfeksiyonu oranı ile ilişkilidir.

Anahtar kelimeler: Cerrahi yara enfeksiyonu; kontaminasyon; enfeksiyon; antibiyotik; tedavi; yara.

\section{INTRODUCTION}

Surgical site infection (SSI) has always been a major complication of surgery and trauma and has been documented for 4000-5000 years (1). SSIs, previously called post operative wound infections, result from bacterial contamination during or after a surgical procedure. Surgical site infections are the third most common hospital associated infection, accounting for $14-16 \%$ of all infections in hospitalized patients (2).

The criteria used to define surgical site infections have been standardized and described three different anatomic levels of infection: superficial incisional surgical site infection, deep incisional surgical site infection and organ/space surgical site infection (2). According to the degree of contamination wounds may be classified as clean, potentially contaminated, contaminated, and dirty (3).

One study among 322 children surgical patients in Nigeria reported high SSI rate of $25.8 \%$ in emergency procedures in contrast to $20.8 \%$ in elective procedures, although the association was not statistically significant (4). Also a similar study documented high rate of SSI in dirty surgery $(60 \%)$ compared with contaminated $(27.3 \%)$, clean contaminated (19.3\%) and clean surgery (14.3\%), the association being statistically significant (4). Studies have shown that introduction of minimal invasive surgery like laparoscopic surgery has resulted in decrease in incidence of SSI (2). Surgical antibiotic prophylaxis was appropriately provided in $93 \%$ of procedures likely contributing to low SSI rate (5).

\section{MATERIAL and METHOD}

Aims and objectives are to establish the pattern of wound infection in terms of aerobic organisms after contaminated and infected surgical procedures. 50 patients having emergency or elective traumatic or nontraumatic abdominal operations who fulfil the criteria of infected and contaminated wounds are included in the study. Selection of patients;

\section{Inclusion criteria}

The patients having emergency or elective traumatic or non-traumatic abdominal operations who fulfil the criteria of infected and contaminated wounds. Operation carried out at Tertiary care Medical school.

\section{Exclusion criteria}

Class 1 and class 2 wounds are excluded.

Study procedure

After admission short history was taken and physical examination was conducted on patient with acute abdomen. Informed written consent was taken from the patients or their guardian willing to participate in the study.
Study population

A. Category-1; (Contaminated: Class III of Altemeier): The group included patients of contaminated surgical procedures like when a hollow muscular organ was opened with gross spillage or acute inflammation without pus formation was encountered. A traumatic wound less than 4 hour old also fall in this group.

B. Category-2; (Infected/dirty), In this group appendicular perforation, primary peritonitis; drainage of intra-abdominal abscess were studied. Traumatic wounds more than 4 hours duration was also included in this group. "Patients to be studied were selected in random basis"

A-Per operative- Swab culture, peritoneal fluid culture in syringe, tissue, and pus.

B-Post operative- On 3rd/4thpost-operative day wound exudate $\{$ if present $\}$ Wound swabs $(2$ in nos.)/Pus in syringe/Tissue

Sample are processed for Aerobic culture and antibiotic sensitivity (Figure 1-3).

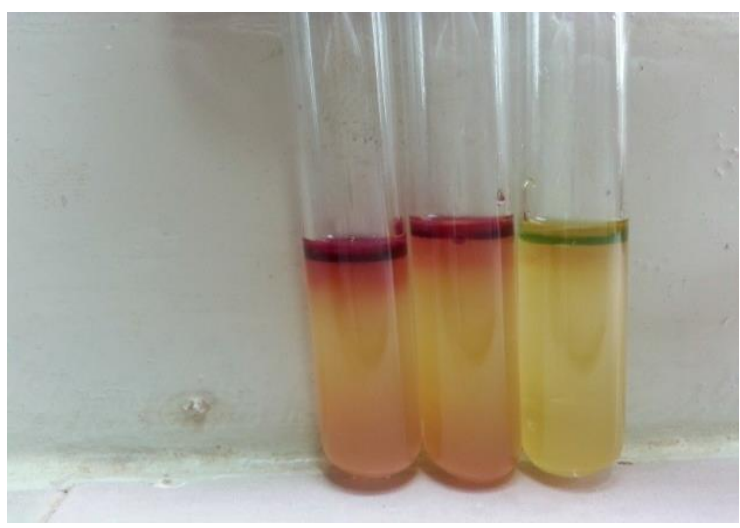

Figure 1: Indole test.

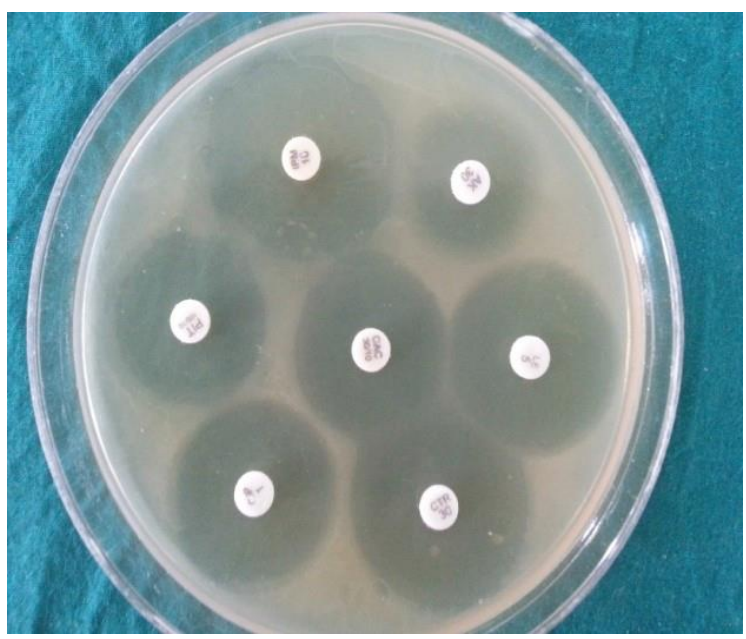

Figure 2: Antibiotic sensitivity test by Kirby Bauer disc diffusion test on $100 \mathrm{~mm}$ plate. 


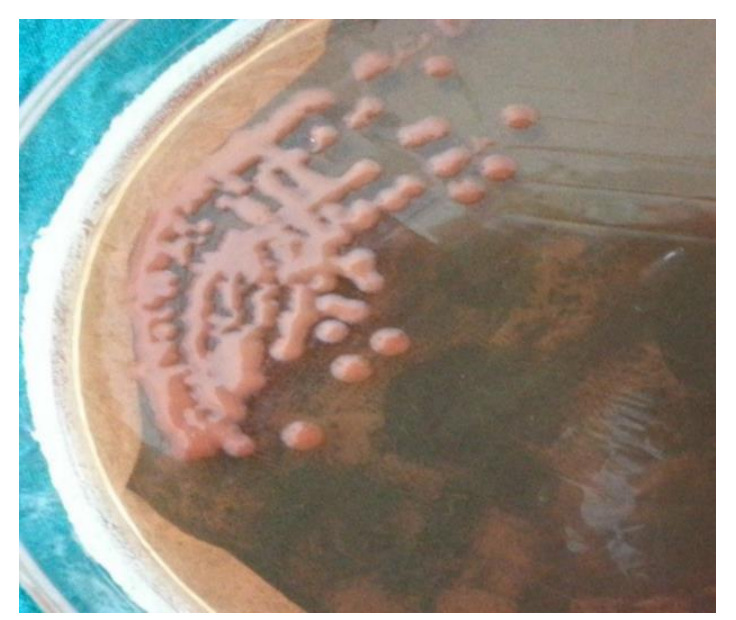

Figure 3: Lactose fermenting mucoid colonies of Klebsiella pneumoniae on Macconkey agar.

\section{RESULTS}

The study consists of 50 cases who were operated at a tertiary school, either as an emergency or elective case during the period of April 2011 to April 2013. All cases are investigated and observed under material and methods. Out of the 50 patients studied 19 are from contaminated group and 31 are from infected group. Amongst the contaminated group, only 8 had surgical site infection whereas in infected group $13 \mathrm{had}$ surgical site infection (Table 1-5).

\begin{tabular}{|l|c|c|c|}
\hline \multicolumn{3}{|c|}{ Table 1: Overall incidence of wound infections. } \\
\hline No of cases & $\begin{array}{c}\text { Contaminated } \\
(\mathrm{n}=19)\end{array}$ & $\begin{array}{c}\text { Infected } \\
\mathrm{n}=31\end{array}$ & $\begin{array}{c}\text { Total } \\
50\end{array}$ \\
\hline $\begin{array}{l}\text { With wound } \\
\text { infection }\end{array}$ & 6 & 9 & 15 \\
\hline
\end{tabular}

\begin{tabular}{|l|c|c|c|c|}
\hline \multicolumn{1}{|c|}{ Table 2: Distribution of patients in infected group (n=31). } \\
\hline \multicolumn{1}{|c|}{ Nature of illness } & Number & Intraoperative bacteriology & $\begin{array}{c}\text { Incidence } \\
\text { of SSI }\end{array}$ & $\begin{array}{c}\text { Bacterial growth in } \\
\text { wound }\end{array}$ \\
\hline $\begin{array}{l}\text { Duodenal ulcer perfora- } \\
\text { tion }\end{array}$ & 09 & $\begin{array}{c}\text { E. coli-5, Klebsiella-2 } \\
\text { BH Streptococci-1, } \\
\text { Staph. aureus-1 } \\
\text { No growth-1 }\end{array}$ & 02 & $\begin{array}{c}\text { E. coli-1 } \\
\text { Stap. aureus-1 } \\
\text { No growth-07 }\end{array}$ \\
\hline Enteric perforation & 09 & $\begin{array}{c}\text { E. coli-4, Klebsiella-4 } \\
\text { BH Streptococci-1 } \\
\text { No growth-3 }\end{array}$ & 03 & $\begin{array}{c}\text { E. coli-1, Klebsiella-1 } \\
\text { Staph. aureus-1 } \\
\text { No growth-06 }\end{array}$ \\
\hline Intra-abdominal abscess & 03 & $\begin{array}{c}\text { E. coli-0, Klebsiella-2 } \\
\text { No growth-1 }\end{array}$ & 02 & $\begin{array}{c}\text { Staph. aureus-01 } \\
\text { No growth-01 }\end{array}$ \\
\hline Gallbladder perforation & 01 & $\begin{array}{c}\text { E. coli-1, Klebsiella-0 } \\
\text { No growth-0 }\end{array}$ & -- & $\begin{array}{c}\text { No growth-01 } \\
\text { Kochs }\end{array}$ \\
\hline Appendicular perforation & 05 & $\begin{array}{c}\text { E. coli-3 } \\
\text { No growth-0 } \\
\text { No growth-1 }\end{array}$ & 2 & $\begin{array}{c}\text { Staph. aureus-2 } \\
\text { No growth-01 }\end{array}$ \\
\hline Large bowel surgery & 01 & Klebsiella-1 & 1 & No growth-05 \\
\hline
\end{tabular}

\begin{tabular}{|l|c|c|c|c|}
\hline \multicolumn{1}{|c|}{ Table 3: Distribution of patients in contaminated group (n=19). } \\
\hline Nature of illness & $\begin{array}{c}\text { Patients } \\
(\mathbf{n})\end{array}$ & $\begin{array}{c}\text { Intraoperative } \\
\text { bacteriology }\end{array}$ & $\begin{array}{c}\text { Incidence } \\
\text { of SSI }\end{array}$ & $\begin{array}{c}\text { Bacterial growth in } \\
\text { wound }\end{array}$ \\
\hline Colonic surgery & 2 & $\begin{array}{c}\text { E. coli-1, Klebsiella-1 } \\
\text { No growth-0 }\end{array}$ & 2 & $\begin{array}{c}\text { E. coli-2 } \\
\text { No growth-0 }\end{array}$ \\
\hline Fresh traumatic wound & 2 & $\begin{array}{c}\text { E.coli-0, } \\
\text { BH Streptococci-0 } \\
\text { No growth-2 }\end{array}$ & - No growth-2 \\
\hline Small bowel surgery & 9 & $\begin{array}{c}\text { E. coli-6, Klebsiella-3 } \\
\text { No growth-0 }\end{array}$ & 3 & $\begin{array}{c}\text { E. coli-01, Klebsiella- } \\
02\end{array}$ \\
\hline $\begin{array}{l}\text { Appendicectomy for } \\
\text { Acute Appendicitis }\end{array}$ & 6 & $\begin{array}{c}\text { E. coli-2, Klebsiella-1 } \\
\text { Streptococcus fecalis-1 No } \\
\text { growth-2 }\end{array}$ & 2 & $\begin{array}{c}\text { E. coli-01 } \\
\text { Staph. aureus-01 } \\
\text { No growth -04 }\end{array}$ \\
\hline
\end{tabular}




\begin{tabular}{|} 
Table 4: Relationship between intra-operative \\
bacteriology of the wound to that of wound \\
infection. \\
\hline $\begin{array}{c}\text { Intraoperative } \\
\text { bacteriology }\end{array}$ & $\begin{array}{c}\text { Patients } \\
\text { (n) }\end{array}$ & $\begin{array}{c}\text { Wound infec- } \\
\text { tion (n) }\end{array}$ \\
\hline Contaminated & & \\
\hline+ & 15 & 5 \\
\hline- & 4 & 1 \\
\hline Infected & & \\
\hline+ & 25 & 7 \\
\hline- & 6 & 2 \\
\hline
\end{tabular}

The following results could be drawn from the study on 50 patients, from both contaminated and infected group who underwent operations either on emergency basis or on routine basis;

1. The incidence of wound infection is $31.57 \%$ in contaminated surgical procedures and $29.03 \%$ in infected surgical procedure.

2. The variation of wound infection was not significant.

3. Operation in emergency set up results in an increased risk of wound infection.

4. Patients with positive intra operative bacteriology runs a higher risk of developing wound infection.

5. The commonest organism isolated from intra operative swab cultures were E. coli followed by Klebsiella in both infected and contaminated procedures.

6. Presence of polymicrobial flora in intraoperative swab culture is associated with higher rate of wound infection.

7. Patients of infected group are more likely to have wound infection with the same organism present in the wound per operatively.

8. Septic complication like wound site infection was the most common pattern seen in patients.

9. Staph Aureus was found to sensitive to Vancomycin, Tiecoplanin, Linezolid whereas Streptococcus was sensitive to Levoflox, Ampicillin and Vancomycin.

10. E. coli, Klebsiella were found to hav sensitivity towards Amikacin, Levofloxacin.

\section{DISCUSSION}

In spite of the development of latest techniques in surgery and recent advancements in antimicrobial therapy. Surgical sepsis remains the most frequent single cause of death after surgery(Wilson 1985 ). The overall incidence of wound infection has been variously quoted from 4 to $40 \%(31.5 \%$ and $29.03 \%$ incidence amongst contaminated and infected groups respectively.

\begin{tabular}{|c|c|}
\hline $\begin{array}{r}\text { Table 5: Sensitivity of gram } \\
\text { Antibiotics (S. }\end{array}$ & $\%)$ \\
\hline Vancomycin & 91.5 \\
\hline Teicoplanin & 91.1 \\
\hline Linezolid & 90 \\
\hline Levofloxacin & 87.5 \\
\hline Netilmycin & 81.8 \\
\hline \multicolumn{2}{|c|}{ Antibiotics (Streptococcus) } \\
\hline Levofloxacin & 100 \\
\hline Ampicillin & 100 \\
\hline Vancomycin & 100 \\
\hline Piperacillin tazobactam & 87 \\
\hline Azithromycin & 75 \\
\hline \multicolumn{2}{|c|}{ Antibiotics (E. coli) } \\
\hline Imipenem & 100 \\
\hline Amikacin & 84.6 \\
\hline Piperacillin tazobactam & 84.6 \\
\hline Gentamicin & 69.2 \\
\hline \multicolumn{2}{|c|}{ Antibiotics (Klebsiella) } \\
\hline Levofloxacin & 100 \\
\hline Imipenem & 90.9 \\
\hline Amikacin & 83.3 \\
\hline Piperacillin tazobactam & 75 \\
\hline \multicolumn{2}{|c|}{ Antibiotics (Enterococcus) } \\
\hline Imipenem & 100 \\
\hline Amikacin & 63.6 \\
\hline Levofloxacin & 63.6 \\
\hline Ceftazidime clavulanic acid & 63.6 \\
\hline Piperacillin tazobactam & 54.5 \\
\hline
\end{tabular}

Our study shows that the incidence of wound infection in two groups, contaminated and infected .Apparently, The maximum incidence of wound infection was noted in patients with enteric perforation. No wound infection was seen after appendicular perforation. This finding may probably was related to bacterial load and extent of the peritoneal soiling as well as the duration of illness.

Our study showed a definite increase in wound infection amongst patients of infected category (1in3), where the intraoperative bacteriology was positive

While in the contaminated group, half of the patients with negative bacteriology at operation developed wound infection.

In our study, the source of infection in $50 \%$ cases was endogenous and $50 \%$ exogenous. Thereby indicating intraoperative bacteriological environment of the wound is not a singular determinant of wound infection. 


\section{REFERENCES}

1. Williams NS, Bulstrode CJK, O'conel PR. Bailey and Love's Short Practice of Surgery, 25 th Ed. London, Hodder Arnold, 2008, p:32-48.

2. Doharty GM, Way LW. Current Surgical Diagnosis, 12th Ed. McGraw Hill, USA; 2006, $\mathrm{p}: 106-7$.

3. Kirk RM, Ribbans WJ. Clinical surgery in general (RCS course manual), 4th Ed. Churchill livingstone, London, UK, 2004, p:206-382.

4. Ameh EA, Mshelbwala PM, Nasir AA, Lukong CS, Jabo BA, Anumah MA, et al. Surgical site infection in children: prospective analysis of the burden and risk factors in a sub-Saharan African setting. Surg Infect (Larchmt) 2009;10:105-9.

5. Merrer J, Girou E, Lortat-Jacob A, Montravers P, Lucet JC. Surgical site infection after surgery to repair femoral neck fracture: a French multicenter retrospective study. Infect Control Hosp Epidemiol 2007;28:1169-74 